\title{
Putting technology to good use for society: the role of corporate, competition and tax law
}

\author{
JOHN ARMOUR, LUCA ENRIQUES, \\ ARIEL EZRACHI and JOHN VELLA
}

\begin{abstract}
Innovation and its main output, technology, are changing the way we work, socialise, vote, and live. New technologies have improved our lives and made firms more productive, overall raising living standards across the world. Thanks to progress in information technology, the rate of change is accelerating. Disruption and disequilibrium are the new normal. In this essay, prepared as a chapter for the first phase of the British Academy 'The Future of the Corporation' initiative, we reflect upon the role that corporate, competition, and tax law can play both to facilitate innovation and simultaneously assuage emergent societal risks arising from new technologies. We consider means of enhancing investment in research and development ('R\&D') and optimising corporate organisation. But we also reflect on the risks associated with innovation, such as the use of technology to exploit consumers, manipulate markets, or distort, unwittingly or not, the political process. Finally, we consider the way in which the environment for business law reform is subject to new political risks following the challenge to the liberal order from populism and the rising power of dominant technology companies.
\end{abstract}

Keywords: Competition law, corporate law, disruption, innovation, law reform, populism, R\&D, tax law, technology.

\section{EXECUTIVE SUMMARY}

Society's primary challenge today is to cope with the effects of accelerated innovation and the disruptive technologies it generates. This paper focusses on the ways in which business law (comprising corporate, competition, and tax law) can be moulded to both facilitate innovation and assuage emergent societal risks.

It considers means of enhancing investment in research and development and optimising corporate organisation, but also the risks associated with, for example, the use of technology to exploit consumers, manipulate markets or - unwittingly or notdistort the political process. 
Artificial intelligence, algorithms, platforms, and distributed ledger technologies are changing the scope of business activity and leading to greater substitutability of firms. Policymakers can use business law to promote innovation but also deter the use of exclusionary or exploitative technology.

The authors consider the challenges for law and regulation associated with financing innovation-focussed businesses. Competition may increase the incremental profit from innovating but may also reduce innovation incentives for laggards. The trend towards concentration in many key sectors of the economy affects not only levels of innovation, but also its nature. Increased market concentration is correlated with significant increases in markups between prices and marginal costs.

With business success and consumer welfare ever-more dependent on innovation and $\mathrm{R} \& \mathrm{D}$, the focus of corporate governance, antitrust legislation, and taxation must shift to account for this new reality. The paper suggests a potential role for public subsidies for $R \& D$, raising finance for innovative projects and the impact of changes in corporate ownership on innovation. An increasing number of countries incentivise $R \& D$ activity through the tax system.

Businesses also have to respond to increasing digitalisation, the rise of 'smart contracts, as an alternative to the corporate form, and the associated potential for regulatory arbitrage. Digitalisation is set to have a major impact on the incidence of agency costs within firms. New technologies have implications for external regulation and corporate compliance, the implementation of systems of internal control, and the international corporate tax system.

Two possible, interlocking, solutions to the currently weak incentives to invest corporate resources in compliance would be to lengthen the vesting period for managerial compensation and institute personal compensation clawbacks and/or personal liability for compliance. Mandating disclosure on compliance programmes would also immediately remove the fear of creating an adverse signal by voluntary disclosure, and permit greater scrutiny of a firm's activities.

To address the fact that, in a time of rapid technological change, regulation lags the emergence of actual risks, the authors propose a dynamic system of forward compliance, where the firm focusses not just on applicable rules, but also on their potential trajectory. Firms therefore start to act in terms of ethics and compliance, rather than compliance alone, and lead rather than follow regulatory guidance.

The paper considers the ways in which the environment for business law reform is subject to new political risks, following the threats to the liberal order coming from populism and the rising power of dominant technology companies. New technologies have spurred globalisation and made migration easier by reducing the risks of moving away from home. Cross-border trade has raised living standards in lower-income countries but also concentrated wealth in high-income countries. 
Political dynamics may change in directions that are hard to predict, with profound implications for the ability of policymakers to implement any programme of reforms. Intellectual and regulatory capture is another force that may distort lawmakers' and policymakers' priorities and preferences.

\section{INTRODUCTION}

Innovation and its main output, technology, are changing the way we work, socialise, vote, and live. New technologies have improved our lives and made firms more productive, raising living standards overall across the world. Thanks to progress in information technology, the rate of change is accelerating. Disruption and disequilibrium are now commonplace.

In this essay, we reflect upon the roles that corporate, competition, and tax law (hereinafter, collectively, 'business law') can play both in facilitating innovation and simultaneously assuaging emergent social risks arising from new technologies. We consider means of enhancing investment in research and development ('R\&D') and optimising corporate organisation. At the same time, we also reflect on risks associated with innovation - such as the use of technology to exploit consumers, manipulate markets, or even distort the political process.

The paper is structured as follows: in Section 2, we consider the challenges for law and regulation associated with financing innovation-focussed businesses. We focus here on questions regarding public subsidies for $R \& D$, the challenges of raising finance for innovative projects, and the impact of changes in corporate ownership on innovation. In Section 3, we turn to the challenges for business organisation posed by 'digitalisation': the use of 'smart contracts' as an alternative to the corporate form and associated potential for regulatory arbitrage; the challenges posed by emergent risks in technology both for external regulation and corporate compliance; the corporate governance problems associated with the implementation of systems of internal control; and the challenges digitalisation poses for the international corporate tax system. In Section 4, we consider the way in which the environment for business law reform is subject to new political risks following threats to the liberal order coming from populism and the rising power of dominant technology companies. These threats have profound implications for the ability of policymakers to implement any programme of reform. Section 5 briefly concludes. The Appendix identifies key points for future research in this area. 


\section{FINANCING INNOVATION-FOCUSSED BUSINESSES}

With business success and consumer welfare ever-more dependent on innovation and $\mathrm{R} \& \mathrm{D}$, the focus of corporate governance, antitrust legislation, and taxation has to shift to account for this new reality. In relation to this theme, we note four key issues: (1) the relationship between profitability, market power, and investment in innovation; (2) positive externalities; (3) financing capacity; and (4) the nature of innovation. We consider each in turn.

\subsection{Market dynamics and the level of innovation}

The digital landscape is characterised by an ongoing flurry of start-ups, adoption of new technologies, and the rise and fall of market players. However, despite this seemingly fertile environment, there are emerging signs that business dynamism and entrepreneurship are falling short of their potential (OECD 2017a).

The relationship between investment in innovation and market dynamics has long been theorised and studied. According to the Schumpeterian hypothesis, market concentration is understood to allow internalisation of the rewards flowing from innovation efforts (Schumpeter 1942). The Arrow hypothesis suggests, on the other hand, that competitive pressure forms the key to investment in innovation (Arrow 1962). A synthesis of both is reflected in the inverted U-relationship, according to which competition may increase the incremental profit from innovating (the 'escape-competition effect') but may also reduce innovation incentives for laggards (the 'Schumpeterian effect') (Aghion et al. 2005).

Recent empirical work provides indications that increases in market concentration are correlated with significant increases in markups between prices and marginal costs in developed economies. In line with the inverted U-relationship, the high markups observed were correlated initially with increasing and then with decreasing innovation rates (De Loecker \& Eeckhout 2018, Gutiérrez \& Philippon 2017). 'This non-monotonicity is more pronounced for firms that are closer to the technological frontier. More concentrated industries also feature a more negative relation between markups and investment and innovation' (Díez et al. 2018).

Ensuring ongoing investment in innovation requires a careful balancing of market dynamics, corporate incentives, and access to capital. High markups do not provide a guarantee for investment in innovation. To identify optimal regulatory structure and enforcement regimes, investment in innovation should be assessed alongside market concentration, barriers to entry, likely disruption, and other industry characteristics. 


\subsection{Positive externalities}

Investments in R\&D frequently yield positive externalities (Haskel \& Westlake 2018): that is, return on R\&D investment is not fully appropriated by the entrepreneur but is captured by other firms that pursue complementary innovations. This suggests a potential role for government policy to stimulate $\mathrm{R} \& \mathrm{D}$.

The literature examining the relationship between public subsidies for $R \& D$ and private R\&D investment has long been equivocal (David et al. 2000). One group of studies report substitution effects, with public investment 'crowding-out' private investment in R\&D (e.g., Marino et al. 2016). On this view, there are a finite number of good projects at any one time, and if (some of) these receive financing from the state, private parties will not wish to finance less attractive projects.

Another group of studies report complementarities, whereby public subsidies are associated with greater and more effective private R\&D investment (e.g., Azoulay et al. 2017). A plausible channel is that outputs from public R\&D investment generate new opportunities for firms to exploit technological complementarities, which in turn stimulate follow-on private $R \& D$ investment. In recent literature, the balance of results has given more support to the complementarities view, especially with respect to tax credits (Becker 2015). ${ }^{1}$ The UK's level of government investment in R\&D trails many other developed countries, and so does its corresponding level of private $R \& D$ (Royal Society 2018). Based on the emerging picture from the more recent research, it appears desirable for more public investment to be made.

\subsection{Financing capacity}

Positive externalities mean that only a subset of the return on R\&D investment is appropriable by an entrepreneur. Even within that subset, the 'assets' generated by R\&D have curious characteristics that intensify the challenges associated with raising outside finance (Hall \& Lerner 2010). R\&D assets frequently take the form of ideas or opportunities that are protected incompletely, if at all, by property rights. Their non-appropriable nature makes it impossible for investors to liquidate them in case of non-payment. This makes R\&D assets, at least until they have been reduced to transferable intellectual property such as patents, unattractive for debt financiers. In contrast, outside equity is more appropriate as a source of finance, because

\footnotetext{
${ }^{1}$ An increasing number of countries incentivise $R \& D$ activity through the tax system. The design of these policies varies across countries and over time, but empirical studies broadly find them to have a positive effect on firm-level and aggregate R\&D spending for firms which are already engaged in such activity in a given jurisdiction (Guceri, 2016).
} 
participation in upside pay-offs reduces the importance of lack of downside protection (Aghion et al. 2004, Berger \& Udell 1998, Carpenter \& Petersen 2002).

Moreover, the results of R\&D expenditure are opaque-they are difficult to interpret by persons not expert in the technology and cognisant of the details of a firm's existing operations. This opacity increases asymmetry of information between investors and entrepreneurs. Where finance is raised at arm's length from public equity markets, adverse selection concerns may lead investors to discount projects that are hard to value (Bernstein 2015, Fang et al. 2014, He \& Tian 2013, Stein 1988). A growing literature suggests this can induce entrepreneurs to redirect effort toward less opaque, but also less innovative and less profitable projects. This problem can be overcome by concentrated investors, who are willing to devote sufficient resources to understand the opportunities in question and thereby overcome the information asymmetry (Aghion et al. 2013, Bushee 1998, Gompers \& Lerner 1999, Kaplan \& Strömberg 2003). However, as noted in Section 2.1, market dynamics may influence their incentive to invest.

Investors' incentives may undermine the public value that $R \& D$ investment generates. Increasing levels of concentration in the technology sector raise the prospect of trade buyers using accumulated rents to invest in ways that stifle innovation. Such firms may support innovation that promotes their commercial interest, while they control, and then suffocate, strands of innovation which may disrupt their own business models.

Furthermore, the volatility of outcomes is high (Gilson 2003, Nanda \& Rhodes-Kropf 2016). This makes learning about a technology itself a very risky investment. It is consequently desirable to diversify such investments across a portfolio of projects that require similar technical expertise to understand. Such knowledge in turn can be leveraged by raising capital from outside investors, but this again creates problems of opacity.

These problems are managed by outside investors co-investing alongside a technical expert manager. Examples of this structure include: (i) venture capital funds; ${ }^{2}$ (ii) 'concentrated' institutional investors, who adopt a buy-and-hold strategy for significant stakes in innovating firms; and (iii) public firms that have durable founder control ('DFC') structures such as dual-class stock. Their comparative performance in facilitating the appropriate development (or not) of particular R\&D assets is an important research question.

Specific research questions arise as respects each of these three structures for financing innovation. ${ }^{2}$ While venture capitalists have traditionally played an important role in supporting innovation, some
argue that they have recently come to favour investment in proven firms and technologies (Krumm 2018). 


\section{Venture capital}

A UK-specific research question is why there is not greater provision of early-stage venture capital financing. The UK has a very large private equity sector relative to GDP, but the vast majority of the private equity funds invested are in buyouts of existing public companies, as opposed to venture capital backing early start-ups. In contrast, the UK's level of venture capital investment relative to GDP is small internationally and has shrunk in recent years (OECD 2017b: 125). In 2016, only 3.5 per cent of the total private equity funds invested in UK companies took the form of venture capital (BVCA 2017: 5). Is this because of lack of opportunities for investment? Or is it because of a 'crowding-out' effect of easy access to public firm targets for buyouts, facilitated by a prohibition on defensive tactics for public company boards?

\section{Concentrated institutional investment}

The presence of (large) institutions all holding shares in each company within the same industry, while raising concerns from an antitrust perspective (Azar et al. 2018, Elhauge 2015, Posner et al. 2017), may have a pro-innovation effect, given that the positive externalities and spillovers from each firm's R\&D investment will benefit all portfolio companies of diversified investors. Recent empirical work provides some evidence confirming that common ownership of firms is indeed associated with greater innovation (Anton et al. 2018) and technological diffusion (Geng et al. 2016, Kostovetsky \& Manconi 2018). However, these findings are controversial. Moreover, the channel through which any influence is exercised is not yet well understood: large passive institutions such as Blackrock typically have too few personnel to facilitate the sort of coordination engagement that one would expect to be necessary to deliver these sorts of outcomes. It is also far from clear that horizontal shareholders necessarily prefer spillovers across competitors rather than mutual competition (Enriques \& Romano 2018). Further work into aggregate effects and — especially — case studies of the channels through which any influence is exercised would be most valuable.

\section{Durable founder control (' $D F C$ ')}

DFC structures are controversial because, although they permit founders to make investment decisions without accountability to the stock price (Goshen \& Hamdani 2015), they also greatly increase the potential for agency costs (Bebchuk \& Kastiel 2018). A key policy question is whether such structures should be permitted (at least) at the IPO (initial public offering) stage. The UK's corporate governance environment does not facilitate DFC structures, owing to concern about agency costs. A related policy question is whether constraints on DFC strcutures act as a curb on financing innovative R\&D investments. Yet, one may also question whether DFC companies in 
the technology sector are effectively insulated from the pressure of stock markets: first, their heavy use of restricted stock as incentive compensation for R\&D employees can be seen as a way of signalling the market that key employees are positive about the prospects of their company, which in turn requires founders not to disregard market price signals completely (Armour \& Enriques 2017). Secondly, a corporate governance externality similar to the one highlighted by Acharya and Volpin (2009) for the financial sector might be at work in the technology industry as well: if insulation from stock markets is positive for the long-term success of a tech firm, firms heavily exposed to stock market pressure (that is, non-DFC companies) may have to pay their $\mathrm{R} \& \mathrm{D}$ employees more and adapt to stock markets' shorter time horizon also to enable employees to cash out. DFC companies competing with such firms may have to do the same to attract the best talent.

\subsection{Market dynamics and the nature of innovation}

The trend toward concentration in many key sectors of the economy affects not only the levels of innovation, but also its nature. From a societal perspective it is important to note this qualitative dimension of innovation.

Large corporations may leverage on their big-data, big-analytics, and network-based market power to marginalise competitors and dictate paths for R\&D developments. Limited outside options for consumers in concentrated markets may increase the likelihood of investment in welfare-decreasing innovation. For instance, advanced technology and economies of scale may be used strategically to deter market entry. Under limited competition, innovation may be used to increase product differentiation, reduce interoperability, raise rivals' costs, and push out existing and potential competitors. New technologies may be deployed to slow the adoption rate of rival ones. Lastly, innovation may also be used to cannibalise rival innovation, when new developments are aimed at sidelining the relevance of competing technologies or at diminishing rival's incentives to innovate (Ezrachi \& Stucke 2018).

The drive toward greater investment in innovation should take account of the nature of innovation, as not all investment in $R \& D$ promotes consumer welfare. Subsequently, the goal for policy makers should not be to simply increase the overall level of innovation. Public policy should take note of the qualitative dimension of innovation and shape the legal and financial landscape in ways that reduce firms' incentive/pay-offs to engage in negative innovation, while promoting (or at least not chilling) their incentive to invest in innovation that generally promotes overall welfare. 


\section{DIGITALISATION IN BUSINESS AND ORGANISATIONS}

By 'digitalisation' we refer to the impact of a cluster of emerging technologies that facilitate the execution of tasks by computers. These include (i) 'artificial intelligence' (AI) - the use of algorithms to deliver human-equivalent decision-making in specific contexts; (ii) 'platforms' - the use of connectivity to perform market-making functions; and (iii) distributed ledger (or 'blockchain') technologies and smart contracting - the use of algorithms for secure transaction verification and the automated performance of contracts. In this section, we first of all reflect upon how smart contracts may affect the use of the corporate form. We next look into the lag between new risks associated with new technologies and the regulatory response to such risks. Then, we move to considering the effects of AI on monitoring within firms and how this can significantly reduce intra-firm agency costs. Finally, we outline some possible regulatory responses to the issues highlighted in this section.

\subsection{Smart contracts and firms versus markets}

Will digitalisation have an impact on the scope of business activity that is conducted using the corporate form? As is well known, business activity can be organised either through a series of market contracts, or through coordination within a firm (Coase 1937, Hart 1995, Williamson 1985). Corporate law allows for the creation of a distinct legal personality, which greatly reduces the costs of monitoring investors' behaviour, and ensures that termination of business activities is a matter for collective decision-making rather than individual hold-up (Hansmann \& Kraakman 2000). The advent of 'smart contracts' has the potential greatly to reduce the costs of organising business activities by contract, as opposed to using firms (Mayer-Schönberger \& Ramge 2018). ${ }^{3}$ This will likely reduce the scope of business activities for which the corporate form is used as an organising device and therefore the scope of activity governed by corporate law. The issue is not merely a perimeter one.

Greater substitutability of firms and contracts will have significant implications for the application of regulation. To the extent that regulation applies to firms, then regulatory arbitrage may motivate business parties to migrate from the corporate form to market contracts. This is a particular challenge not only for tax policy, but also for competition law, employment law (Birkinshaw 2018, Prassl 2018), and other regulatory regimes.

\footnotetext{
${ }^{3} \mathrm{~A}$ smart contract will securely and automatically disburse payment or deliver the agreed upon service or good on receipt of a digital signal about the other party's performance.
} 


\subsection{Emergent social risks}

A second challenge for corporate law and regulation relates to the management of emergent social risks associated with the manufacture and deployment of digital technologies (Armour 2018). By 'social risk' we refer generally to situations where new technology applied or produced by a firm generates risks for other members of society that were not appreciated until the technology came to be deployed. Examples may include the impact of social media on the democratic process; network externalities associated with the dominance of particular platforms, triggering reduced consumer choice and potential systemic risk through over-reliance on particular solutions; the use of advanced algorithms to engage in personalised price discrimination, enhancing the exploitation of behavioural biases to increase sales and/or enabling the consideration of individuals' membership of protected categories in setting the terms of trade. Such risks can be described as emergent where their extent is not fully appreciated by actors ex ante.

The management of such emergent social risks presents a challenge for regulation (Brownsword \& Goodwin 2012, Sabel et al. 2017) and corporate governance (Armour 2018). The social costs of new technologies are borne, at least in part, by firms that produce or use them. These costs are imposed on the firm either through law (private law liability or regulatory penalties) or reputational sanctions from market actors. However, the internalisation of such costs is likely to be incomplete.

A key problem is that regulatory controls can only be imposed in relation to risks that are understood sufficiently to be regulated, meaning that regulation lags social risks of technology. Generalised tortious liability has the advantage of being capable of being applied on a case-by-case basis by the judiciary (Shavell 1980). However, negligence-based liability does not extend to emergent risks, which would not, by definition, have been 'reasonably foreseeable' at the time of the activity in question.

Insofar as there are 'regulatory lags', firms seeking to maximise profits for shareholders will have incentives to create social costs. One family of solutions would be to place the onus on firms producing or deploying new technologies to assure their safety. This would encompass:

1. Pre-emptive regulatory controls, where firms are prohibited from certain types of activity unless they can demonstrate to regulators their safety. An example of such a regime is the US Food and Drug Administration (FDA) licensing process for medicines.

2. Strict liability, whereby actions that cause harm to others attract liability without any need to demonstrate the foreseeability of such harm (Shavell 1980). For example, the European Product Liability Directive (85/374/EEC) imposes a strict liability standard on manufacturers of products. 
This family of solutions shares a generic problem: it has an adverse impact on incentives to innovate. For this reason, the European Product Liability Directive offers a defence for producers who can establish that harm was caused by defects that were not foreseeable at the time of manufacture given the extant state of technology - the so-called 'development risk defence' (Art 7(e)). This effectively makes liability negligence-based in respect of such risks. The difficulties associated with quantifying any function of social welfare involving the (as-yet-unknown) benefits of future innovation means that it is hard to calibrate any clear policy implications. This is not a new problem, but rather has manifested itself in a structurally similar form since at least the industrial revolution (Horwitz 1979).

At a less abstract level, there are practical limitations with both major versions of this family of solutions. Pre-emptive regulation of conduct requires that the conduct in question be specified: this itself is likely to be a source of regulatory lag in the case of rapidly evolving technological change. Strict liability, on the other hand, may tend to bias innovation towards small firms and subsidiaries, which can take advantage of limited liability to shield investors from liability (Easterbrook \& Fischel 1991, Hansmann \& Kraakman 1991).

\subsection{Corporate reputation and emergent social risks}

Firms whose activities cause social harms may suffer 'reputational' losses. We characterise reputation in two distinct senses, which we label 'market' and 'political', respectively. A firm's market reputation consists of the expectations of its customers and investors regarding the quality of its future performance. Firms that consistently meet or exceed contractual expectations develop a reputation for good performance which enables them to enjoy enhanced terms of trade. Conversely, a revelation that a firm's activities cause harm to its customers or investors may trigger a downward shift in their expectations of its future performance, worsening the terms of trade it can command.

Studies of market reputational losses following legal enforcement suggest that causing harm to third parties who do not deal with the firm (for example, environmental torts) does not result in any additional reputational losses (Armour et al. 2017, Karpoff et al. 2005, 2008). The implication of this literature is that, where emergent technological risks in a firm's activities cause harm to its customers, the firm will internalise this cost in market reputational loss. But where the harm is to third parties, it will not.

We characterise a firm's political reputation as the public perception of the firm's activities in the media. ${ }^{4}$ Rational politicians respond to the concerns salient to voters,

${ }^{4}$ This may plausibly reflect concerns about managers' personal reputation as much as the reputation of their firms (Bednar, 2012). 
as this may be expected to win votes. Where the firm's activities attract negative coverage, then this may generate sufficient salience for politicians to take an interest (Culpepper 2011). A firm may suffer adverse consequences in the form of heightened probability of investigation or enforcement action being taken against it by public authorities (Dyck et al. 2008), or possibly a reduced likelihood of success in a public procurement competition. The difference between political and market reputation is that a firm's political reputation may potentially be damaged by harm caused to third parties by its activities. Conversely, a firm may seek to enhance its political reputation by engaging in activities that demonstrate its commitment to social responsibility. ${ }^{5}$

While the empirical literature is equivocal as to whether political reputation is a measurable channel through which a firm's value is affected, some studies do report positive valuation effects of corporate social responsibility (CSR) investments that benefit the environment, consistent with this view (Flammer 2012). An alternative interpretation is that CSR investment is actually a proxy for compliance activity, meaning that such firms are likely to incur reduced penalties should they be on the receiving end of enforcement actions (Godfrey et al. 2009). In order to achieve a clean identification of the political reputation channel, it is desirable to focus on a case where firms make reports regarding their performance vis-à-vis third parties, which does not itself entail any legal risk.

\subsection{Corporate governance and compliance}

Even where a firm's shareholders are in principle made to bear the social costs of its activities through appropriately structured regulation or liability rules, enforcement remains an issue. Enforcement is also usually a necessary trigger for reputational consequences: it lends credibility to allegations through an impartial assessment (Murphy et al. 2009), and often results in the disclosure of considerable amounts of otherwise-private information (Shapira 2018).

Where the probability of enforcement is low, it is necessary to introduce a very high penalty to achieve deterrence by setting the expected cost of non-compliance equal to the social costs of the proscribed conduct. In the context of corporate misconduct, high penalties are not uncommon. For example, BP paid $\$ 62$ billion in fines and clean-up costs after its Deepwater Horizon oil spill, and Wells Fargo has been subjected to an order by the Federal Reserve freezing its growth until compliance failures are remedied, as well as a $\$ 1$ billion fine from enforcement action by two other

\footnotetext{
${ }^{5}$ Culpepper and Thelen (2018) argue social media platform companies such as Google and Facebook mobilise political capital in their own favour by focussing squarely on the provision of salient benefits to their consumers.
} 
regulatory agencies. Moreover, if a firm depends on a regulatory licence, then penalties that remove this licence can effectively force it out of business.

However, imposing very high corporate penalties has real ex post costs: jobs may be lost, and firms forced into bankruptcy. It is against this background that corporate compliance programmes emerged. The basic idea is that, because firms have better information about their employees' character and behaviour than does a regulator, firms can monitor misbehaviour more cheaply than can public authorities, and it is consequently efficient to delegate (Arlen 1994). 'Compliance' is the name given to institutions established internally by firms to carry out such delegated enforcement (Miller 2018). Such institutions can reduce the incidence of misconduct and the need for socially wasteful corporate penalties.

Conflicts may emerge between immediate financial considerations prioritised by managers and the objectives of effective compliance. Executive compensation is typically tightly linked to a firm's stock price, so as to encourage focus on shareholder value (Kaplan 2013). This can create conflict over the establishment of a compliance programme, and over how such a programme is run (Arlen \& Kahan 2017, Armour et al. 2018a).

To see how such costs could emerge, note that, although establishing a compliance programme can reduce a firm's expected penalties, doing so sends a compound signal to investors. It signals both (1) that the firm is taking compliance seriously (a good thing for investors) and (2) that the firm considers it is appropriate to take compliance seriously. This second component may have a negative impact on the stock price. Ceteris paribus, whether the firm thinks it is appropriate to invest in compliance is a function of the likelihood of enforcement. Consequently, a firm that discloses a compliance programme signals that it anticipates it has a relatively high chance of attracting enforcement (Armour et al. 2018a, 2018b). Although the fact that the firm is taking compliance seriously is good news, the net effect of the signal is likely to be negative. Consequently, managers seeking to maximise the stock price will prefer not to disclose details of a firm's compliance activities. Consistently with this proposition, firms do not voluntarily disclose any meaningful information about their compliance activity (Griffith 2016).

Because investment in compliance is typically not disclosed to the market, this means that it suffers from the same problem we described in Section 2.3 regarding innovative activity: investors will not reflect its value in their assessment of the stock price (Armour et al. 2018a). As a consequence, managers who are concerned to maximise the stock price will have incentives to under-invest in compliance relative to what is in the long-term interests of the shareholders. 


\subsection{Digitalised monitoring as an imperfect solution}

Digitalisation will permit more effective monitoring via a wider range of employee and manager performance measurement tools (Bamberger 2010, PwC 2018). In the medium to long run, the deployment of artificial intelligence raises the prospect of a significant reduction in agency costs within firms. However, taking advantage of these tools effectively requires those in charge of directing the programme to ensure it is appropriately designed.

This merits careful further study. Unless performance measurement mechanisms encompass all dimensions of performance, they are likely to intensify problems of 'skew' in performance towards those aspects that are measurable. More generally, the way in which the goals of the AI algorithms are defined and the extent to which they contain inbuilt reference to compliance with generally binding norms become a key strategic question for firms as well as policymakers (Hadfield-Menell \& Hadfield 2018). In short, the incentives of the persons designing a firm's internal performance monitoring systems are likely to become even more significant. To the extent that a firm's corporate governance fails to give social-welfare compatible incentives, it will accentuate firms' socially harmful behaviour.

\subsection{Possible responses}

We have described interlocking problems with social costs generated by digital technologies adopted or produced by corporations: under-regulation of emergent risks and short-termism regarding corporate investments in compliance activities and systems. Under-regulation of emergent risks means that shareholder value may be enhanced by activities that are socially harmful. We have also noted that agency costs as between managers and shareholders are likely to lead to short-termism in compliance, even where regulation is present. Here we outline some possible solutions. Like the problems to which they respond, these can also be thought of as interlocking.

\section{Compliance, compensation, and disclosure}

The weak incentives for corporate managers to invest corporate resources in compliance activities can be ameliorated in a variety of ways, which are likely to complement each other.

1. Lengthening the vesting period for managerial compensation. Longer vesting periods lead managers to focus less intensively on the short-term share price consequences of their decisions. In its 2018 version, the UK Corporate 
Governance Code has extended the holding and vesting period for executive stock awards from three to five years (FRC 2016: 24, 2018: 14). In the financial services sector, the UK regulators (Financial Conduct Authority and Prudential Regulation Authority) have recently increased from five to seven years the minimum vesting period for at least 40 per cent of variable pay for senior managers in banking and insurance firms. ${ }^{6} \mathrm{~A}$ drawback with longer vesting periods, however, is that the value of deferred awards are affected by actions taken by a manager's successors, rather than the manager's own actions. Empirical research into the impact of these longer vesting periods would be valuable.

2. Clawbacks andlor personal liability. Managerial incentives can be ameliorated through a design of compensation schemes and/or liability rules sensitive to the consequences for the firm of compliance failures (Armour et al. 2018a). A compelling case can be made for the enhancement of the efficacy of liability rules with respect to compliance. In particular, liability rules currently in place in Delaware (the leading US jurisdiction for corporate law) simply require directors and officers to make a 'good faith' attempt to implement some sort of compliance programme, but do not engage in any scrutiny of the adequacy of a programme that may be implemented. ${ }^{7}$ Turning to the UK, where directors do owe an objective duty of care to monitor the company's compliance activities, ${ }^{8}$ the problem is that the duty is rarely, if ever, enforced in solvent companies (Armour et al. 2009). Where private enforcement is a problem, public enforcement may be a viable alternative. Following a strong recommendation from the Parliamentary Commission on Banking Standards (2013), the UK recently introduced an objective 'duty of responsibility' for senior managers of financial services firms with respect to compliance, backed up by enforcement from the Financial Conduct Authority (FCA 2017). ${ }^{9}$ Evaluating the impact of this regime on the functioning of the financial sector, on executive labour markets, and on the market for non-executive directors could yield useful insights regarding whether similar measures might be appropriate for other sectors.

${ }^{6}$ FCA Handbook, SYSC 19D.3.59, Remuneration Principle 12(g)(1)(b).

${ }^{7}$ In re Caremark International Inc., Derivative Litigation (Del. Ch., 1996). See also Delaware General Corporation Law \$102(b)(7) (permitting firms to exculpate directors from any breach of duty not amounting to bad faith).

${ }^{8}$ Companies Act 2006 s 174; Re Barings plc (No 5) [1999] 1 BCLC 433, aff'd [2000] 1 BCLC 523.

${ }^{9}$ Financial Services and Markets Act 2000, s 66A (as amended by Bank of England and Financial Markets Act 2016). The new regime applied initially to banks, from May 2016. It is being extended to insurers and FCA-solo-regulated firms in 2018. 
3. Mandating disclosure about compliance activities. In our analysis, the currently ubiquitous non-disclosure of compliance activities is a central problem plaguing the area. Mandating disclosure of firms' activities to ensure compliance with relevant legal obligations would at one stroke remove the fear of creating an adverse signal by disclosing, and permit investors to scrutinise the adequacy of the firm's activities. Hong Kong companies have since 2014 been required to include in the business review section of their annual reports 'a discussion of their compliance with relevant laws and regulations that have a significant impact on them'. ${ }^{10}$ Studying the impact of this measure and the information content of firms' reporting thereunder is a highly promising avenue for future research. ${ }^{11}$ Some countries also impose disclosure obligations on tax matters. The UK, for example, recently introduced legislation requiring companies to disclose their tax strategies ${ }^{12}$ - although some reservations have been expressed about the extent to which this particular requirement will produce behavioural change (Freedman \& Vella 2016).

\section{Ownership}

A myopic attitude towards emergent social risks, other things being equal, should be less likely if control is locked and controllers are committed to the firm for the long term (Mayer 2013). Neutral policies vis-à-vis corporate ownership structures, possibly allowing for DFC mechanisms and favouring controllers' commitment to their firms, may therefore be considered as part of the solution.

\section{Emergent risks and 'forward compliance'}

The problem of emergent risks reflects the fact that regulatory strictures imposed on firms to encourage alignment with social welfare are, in a time of technological change, necessarily lagging the emergence of the actual risks. At one level, this challenge reflects a social-policy choice: innovation versus social risk, which should be reflected in whether pre-emptive regulation is deployed. However, we see a role for corporate governance in one section of the problem. This is where the firm discovers information about the nature of an emergent risk ahead of the regulator. At this point, the

\footnotetext{
${ }^{10}$ Hong Kong Companies Ordinance (Cap. 622), Schedule 5, para 2(b)(ii).

${ }^{11}$ The UK government is currently introducing measures that will require large UK companies (defined as those with a turnover in excess of $£ 36$ million) to report on how their boards are having regard to the list of various pro-social factors set out in section 172 of the Companies Act 2006 (Companies (Miscellaneous Reporting) Regulations 2018, introducing new section 414CZA to Companies Act 2006). This does not, however, entail any specific obligation to report compliance activities. Given our analysis of companies' incentives, we do not anticipate it will result in significantly increased disclosure of compliance activities.

${ }^{12}$ Finance Act 2016, Schedule 19.
} 
firm likely can determine the existence of social risk, but there is no regulatory prohibition. How should the firm respond?

A firm that does not change its behaviour will not be violating any regulatory requirements, at least until the regulator gets wind of the harm and adjusts the rules accordingly. To be sure, if the risk in question manifests itself as physical harm to persons or property, then it will likely trigger (negligence-based) tortious liability for the firm. However, many losses involving digital assets are economic, for which negligence liability is very difficult to establish.

Clearly, it is undesirable for firms to continue to act in a way that foreseeably causes even economic harm. To respond to this, Armour (2018) proposes an approach termed 'forward compliance': firms' compliance programmes should be dynamic in their orientation, focussing not only on what the applicable rules are at the time of any particular action, but also on their trajectory and the likely regulatory impact of the revelation of any new information available to the firm. In other words, the firm's compliance team should ask themselves, in light of new information, 'how are the regulatory authorities likely to respond to this?' and adjust their compliance programmes so as to deliver conduct consistent with these anticipated regulatory requirements.

This would require firms to adopt a proceduralist approach, with the appropriate question being 'what do the goals of the relevant regulatory regime suggest is an appropriate response to this information?' This imposes a meaningful steer toward reducing externalities: without requiring firms to act as abstract social planners, forward compliance would rather encourage them to situate their analysis in the existing framework. This would also have the beneficial consequence of likely encouraging firms to share information regarding potential social costs with regulators as soon as they become aware of problems, so as to get a steer from the latter and consequently validate the firm's approach to forward compliance.

This 'grounded' approach to forward compliance shifts the burden to regulators: for success, it requires the establishment of clear regulatory goals and the rapid and appropriate response by regulators to revelations from firms. However, where regulators are absent or under-resourced and/or where firms seek to influence regulators' decision-making so as to enhance shareholder returns at the expense of social welfare, then an approach that encourages firms to extrapolate from existing regulatory norms may not be sufficient. It may consequently be desirable for there to be a general or 'background' normative framework against which the firm's forward compliance endeavours should be assessed (Armour 2018). As a normative goal, social welfare maximisation has the appeal of avoiding any particular substantive ethical norms being imposed through the medium of the firm (Heath et al. 2010). An obvious objection would be that firms, especially smaller ones, lack the resources to make 
meaningful assessments under such a metric. Implementation could be sensitive to this by asking only for an assessment to a degree that is proportionate to the firm's resources. Where such a norm may plausibly be most useful is in ruling out activities that clearly harm social welfare - for example, lobbying to avoid regulatory constraints in ways that benefit shareholders at the expense of society.

Forward compliance implies having internal procedures in place that may prompt firms to raise internal standards above those set by the general law or applicable regulation: that is, leading, rather than following, regulatory guidance. For this reason, the term 'compliance' may seem too restrictive; indeed, many firms and their advisers speak of 'ethics and compliance' instead. There is considerable evidence that firms do seek to implement 'ethics' and 'integrity' policies (McBarnet 2007). Several channels already exist through which it may be in shareholders' interests for corporations to pursue pro-social responses to emergent risks:

1. Market reputation: To the extent that emergent risks result in harm to a firm's customers, the firm is likely to suffer reputational harm.

2. Political reputation: Where the resulting harm is felt not by customers but by third parties, the firm's political reputation may nevertheless be adversely affected.

3. 'Normative hindsight': Emergent social risks imply a dynamic trajectory for norms regarding conduct. Actions which are legally permissible at the time they are taken but which are foreseeably socially harmful are likely subsequently to become prohibited. While of course a firm cannot be pursued for conduct that was at the time legal, this might be a factor in the decision (a) whether or not to enforce for subsequent violations under the new regime, and (b), conditional on such enforcement, on the size of the penalties sought.

The obligation to disclose how the board of a UK company are taking into account the list of pro-social factors in section 172 of the Companies Act 2006 may enhance the effectiveness of the reputational channels. ${ }^{13}$

\subsection{Challenges for international corporate tax}

Digitalisation poses a significant challenge to the existing system for taxing corporate profit in an international setting. This is unsurprising given that the basic structure of the system dates back to the 1920s. There is now widespread - although not universal

\footnotetext{
${ }^{13}$ See above footnote 11 and text thereto.
} 
-agreement about the need for reform; however, there are different views on the scope and type of reform necessary. ${ }^{14}$

One view starts by noting that digitalisation exacerbates long-standing problems in the existing system, including economic inefficiency, profit-shifting, and instability due to competition among states (Devereux \& Vella 2017) ${ }^{15}$ Consider profit-shifting as an example. One of the most important channels through which multinationals shift profits from high-tax to low-tax countries is the mispricing of intra-group cross-border transactions. An expanding body of complex hard and soft law is in place to police such transactions by essentially requiring intra-group prices to be aligned with the price that would have been charged by independent parties - the 'arm's length' price. This body of law suffers from considerable conceptual and practical difficulties (Andrus \& Collier 2017), but it has proven to be particularly inept at dealing with 'hard-to-value' intangibles, which are central to corporations' value in a digitalised world.

This analysis leads to a preference for system-wide reform, rather than reform targeting 'digital' or 'highly digitalised' companies. Different options for system-wide reform are then available. ${ }^{16}$ One option starts from the observation that significant problems arise under the existing system because multinationals are taxed in the jurisdictions where their mobile factors are located, including the location of production, R\&D facilities, and intellectual property (IP) (Devereux \& Vella 2014). Under this system, therefore, companies have an incentive to move their real activities (for example, production and R\&D facilities) and profit (for example, by moving their IP) to low-tax countries. ${ }^{17}$ In turn, countries have an incentive to compete through the tax system to attract real activities and profit, leading to a race to the bottom, as evidenced by the steady and widespread decline in corporate tax rates over time. Competitive forces generated under this system thus threaten its long-term viability.

If many of the system's significant problems ultimately stem from taxing companies in the location of mobile factors, they can be addressed directly by moving to a system that taxes companies in the location of immobile factors. As consumers are relatively immobile, one option would be to tax companies in the location of their consumersthe place of destination, in tax-policy jargon. Several studies have examined the

\footnotetext{
${ }^{14}$ OECD (2018) sets out countries' different views on how to address the challenges posed by digitalisation. Broadly, one group of countries favours targeted reform to address specific issues arising from digitalisation, a second group favours system-wide reform, and a third group does not believe reform is necessary for the time being.

${ }^{15}$ These issues are discussed at some length in Desai and Dharmapala (2018).

${ }^{16}$ Some options are also discussed by Desai and Dharmapala (2018).

${ }^{17}$ Note, however, that the ability to shift profits may reduce real economic distortions. Desai and Dharmapala (2018) discuss this further.
} 
properties of, and implementation issues around, corporate tax systems that move towards destination exclusively (Auerbach \& Devereux 2018, Auerbach et al. 2017a, 2017b) or partially (Andrus and Oosterhuis 2017, Avi-Yonah et al. 2009, Fell \& Schreiber 2017).

Another view on how to address the challenges posed by digitalisation focuses on specific challenges, and thus favours more limited reform targeting certain highly digitalised companies. The EU Commission (2018a, 2018b) and HM Treasury (2018) recently put forward reform proposals that are in line with this view. Both proposals seek to address the existing system's failure to take into account the importance of user participation and data for certain highly digitalised companies. Proposals of this kind have attracted support (e.g., Brauner \& Pistone 2017) but also criticism (e.g., Devereux \& Vella 2018). A central concern is that they do not address the fundamental problems that trouble the existing system and threaten its long-term viability.

\section{BUSINESS LAW REFORMS AND THE POLITICAL CLIMATE: CHALLENGES AND RISKS}

We have so far discussed ways in which business law can be modified to enhance innovation and curb the negative effects of technological disruption on society. The current transformation of markets and technologies challenges policymakers to adjust the regulatory landscape and put innovation to good use for the benefit of society.

However, it would be naïve to think of business law production as an aseptic endeavour driven by benevolent social planners. Business law is the outcome of political struggles and negotiations, and businesses are key players in the policymaking process. It is therefore necessary to inject some realism into the discussion about the future of business law and how it can cope with the challenges of technology-driven disruption, and consider it within the framework of the present political crisis of liberal democracies. If populist and/or nationalist tendencies triumph, political dynamics will change in directions that are hard to predict, but the policy suggestions we have so far put forth may well be superseded by more radical alternatives. At the same time, even in the new political environment, large and powerful players may well retain, if not reinforce, their ability to capture the political process and dominate the intellectual discourse, hampering efforts to enact reforms that benefit society as a whole rather than the few.

We thus conclude our discussion on the future of business law with some reflections on the impact on business law of the possible transition from liberalism to populism and of the likely persistence, whether in the new political environment or in liberal democracies, of businesses' ability to effectively influence the political process, which 
digitalisation makes even greater. Here, we take a different tack from previous sections in that, instead of suggesting policies to deal with the consequences of technologydriven change, we show how business law may evolve in a political environment dominated by populism and/or regulatory and intellectual capture.

\subsection{Technology, globalisation, and populism}

The connection between technology and populism immediately appears strong once it is acknowledged that one of the main drivers of populism is globalisation, which has in turn been spurred by technology. Fears about workers' displacement due to disruptive innovation and digitalisation compound those stemming from globalised markets and migration inflows, enhancing the prospects of political forces pushing against the Washington consensus and the end-of-history status quo in Western democracies.

Technological change is behind all past waves of globalisation. Cross-border trade has obviously benefitted from improvements in transportation and distance communications technologies. Advances in transportation technologies have opened up markets to faraway producers, while improvements in information and communication technology have eased control of agency costs at distant production sites and suppliers (e.g., Clemons et al. 1993).

At the same time, technological developments have fostered product innovation and increased productivity in various corners of the world. Lower-cost and better products, in turn, have for long made politicians' attempts to protect domestic markets from foreign competition harder to justify. Finally, technology has contributed to steadier migration flows by reducing the risks and emotional costs of moving away from home, thereby increasing the influx of new workforce in wealthy economies (Collin \& Karsenti 2012).

Increases in cross-border trade and migration flows have led to the horizontal displacement of a significant portion of the workforce in advanced economies and to fears of the same by those who work in sectors open to international competition or in jobs that can be easily taken by immigrants.

These phenomena have been coupled with a second form of displacement: the vertical one deriving from the digitalisation of job tasks. Machines and the highly educated engineers programming them are replacing, or can be feared soon to replace, large chunks of the workforce. While this phenomenon is as old as the first industrial revolution, the recent acceleration in disruptive innovation has made everyone aware that entire industries may soon be automated (Pew Research Center 2017).

Needless to add, the displacement resulting from globalisation and disruptive innovation is not just a matter of fears and perception. While cross-border trade and innovation have resulted in enormous gains from trade and productivity, thus 
contributing to a rapid increase in living standards especially in lower-income countries, these phenomena have also gone together with a growing concentration of wealth within high-income countries (Piketty 2014). Despite accelerating global growth, the income of less-well-off citizens of rich countries has actually flat-lined or declined in real terms (Milanovic 2016). As a matter of sheer politics, it does not matter much whether such outcomes are merely correlated with, or caused by, globalisation and technology. Their impact on the political sphere has been severe.

\subsection{Populism and business law policies}

The political landscape has in fact changed considerably in the last few years. In Western Europe and the US, populism and nationalism are either challenging the old political order or have already replaced it. This has engendered political volatility, with a resurgence of support for policies involving economic nationalism and/or redistribution. The two policy agendas are, in part, severable: right-wing populists focus largely on economic nationalism ('My Country First') and curbs on immigration, leading to a greater role for the state in identifying the 'national interest' that market transactions are to be filtered through. Left-wing populists combine the same idea of a stronger role for the state in the economy, including as the exclusive supplier of some socially relevant and/or politically salient services and products, with a redistributive agenda.

Nationalism and populism are bound to affect corporate, competition, and tax laws. In the area of competition law, nationalism is embedded in the design of the law, which, with the notable exception of the EU, seeks to protect competition in the domestic market. Correspondingly, while subject to ongoing convergence, antitrust enforcement remains national in nature. Being path-dependent, competition law is anchored in historical developments and forms an integral part of a polity's legal, social, and political fabric (Ezrachi 2016). The different scope and role of competition laws around the world have led to some visible differentiation in the application of competition law to digital markets (Ezrachi 2018). Despite the international framework of cooperation, a rise in national sentiment risks turning these inherent differences into political friction and tilting the balance away from harmonisation of enforcement.

Similarly, in the area of taxation, whilst there has for some time been widespread agreement on the need to reform the existing system for taxing corporate profit in an international setting, the debate has been hindered by populist views, including views on the 'fair share' of tax companies ought to pay in the countries in which they operate. Governments are under significant public and political pressure to act swiftly against perceived abuse or flaws in the system, which allow multinationals to pay less than 
their 'fair share' of tax. While this pressure has had the positive effect of pushing forward the debate on much-needed reform, it has also had its drawbacks. It led to the adoption of unilateral measures - such as the UK Diverted Profits Tax-which undermine efforts to seek internationally coordinated reform. It also led to proposals such as the EU Commission's (2018b) proposed Digital Services Tax - essentially a tax on the turnover of certain highly digitalised companies - which its very proponents acknowledge to be problematic. In a leaked document, the Commission made a frank admission reflecting a broader trend in current corporate tax policymaking: 'There is a high political pressure for Member States to adopt short-term measures with a more targeted scope. ... We are nonetheless aware that such a short-term measure is suboptimal and has a series of drawbacks and limitations' (European Commission 2018c).

As the examples of competition and tax law illustrate, the role of the state (and politics) is bound to grow if the current political trends continue. The degree of involvement of the state in an economy is no more a function of the formal rules granting public institutions a say on the functioning of markets than the outcome of broadly accepted beliefs about how far the state can go in exercising its de facto power to obtain desired outcomes. Ideology plays a key role in shaping such beliefs, filtered through the media and politicians' own self-assessment of what is appropriate and what is not. Relatedly, politicians' readiness to accept the boundaries set by economic and policy experts is bound to change if voters' deference to expert opinion changes as well.

Hence, the role of governments in the economy can expand well before the underlying ideological change is reflected in new laws and regulations. That is possible because, first of all, laws and regulations will often be crafted in ways that allow for more political manoeuvre than is actually used in 'normal' political times. Second, any government has ultimately a reserve of 'raw power' that, when political circumstances so allow, can be resorted to in order to obtain the desired behaviour from private economic actors. Dramatic changes in the state's role in an economy can thus take place surreptitiously.

While right-wing and left-wing populism have common traits, which converge into assigning a greater economic role to governments, economic nationalism and redistributive agendas entail distinct effects.

Economic nationalism may increase domestic ownership of corporations, which could imply a reduction in the pool of available capital and therefore an increased role for either entrepreneurial founders/families or the state itself. Nationalism is also likely to resurrect barriers to trade and, in the specific area of corporate law policies, reinforce calls for restrictions on takeovers, whether by foreign or domestic bidders, as we further illustrate in Section 4.4. A less vibrant market for corporate control and the reduced product market discipline induced by protectionism may lead to higher 
agency costs between (minority) shareholders and managers or dominant shareholders, implying a greater need for rules protecting investors, but they may also favour longer term corporate strategies (Pargendler 2018).

In practice, rather than tinkering with the technicalities of corporate law, populist governments may prefer letting controllers loose and retaining the option of disciplining them using their raw power, which they may do both if controllers spectacularly abuse their controlling position or fall from grace with the ruling politicians. We can call this a Russian-style contingent nationalisation of private businesses. It is impossible to tell how far Western democracies will go in that direction. But the Putinian governance model is in clear display on the global arena as a relatively stable, if extreme, model of nationalist/populist economic governance.

The left-wing alternative to disguised nationalisations is, of course, a formal process of (re)nationalising some firms or entire industries. That would be an expedient way of pursuing redistributive agendas in specific sectors, such as public utilities and other services sectors that are protected from international competition. Of course, that would put a drag on the productivity of the sectors that are open to cross-border competition, but protectionist measures, such as tariffs and non-tariff barriers, may be used to reduce the scope of the damage to the sectors that are open to foreign competition.

Less radically, left-wing populism is bound to breathe fresh life into long-standing progressive agendas like embedding a greater 'pro-social' role for corporate actors, including respect for human rights, improved wages and working conditions for employees, and sustainability vis-à-vis the environment. Attention is also likely to be focussed on inequality within the firm: the size of worker pay relative to executive pay and shareholder returns ('socialising gains'), the perception that executives should share in downside losses ('privatising losses'), and issues of gender and ethnic bias in pay being sources of concern in their own right. Whatever their merits, implementation of such policies makes it more difficult to measure operational success than a simple focus on stock price, with the result that managerial agency costs may, again, rise.

All in all, the two trends, economic nationalism and redistributive agendas, encapsulate an economic environment in which politics has a much greater say in how firms are run than we have been used to in the last thirty years. In democratic systems, this may well exacerbate, rather than solve, the perceived short-termism of corporate players, given the short-term horizon of politicians themselves. It also implies an even greater need to expend resources on lobbying activities, whether to hijack nationalistic or redistributive policies to one company's or sector's private goals or to resist undesired outcomes. 


\subsection{Intellectual capture}

The correlation between market power, economic power, and political clout has long been recognised. Key corporate players can influence the legislative and political process through open lobbying and more subtle forms of influence. In doing so they aim to shape the regulatory environment in their favour, externalising risk and costs onto the public or other competitors.

But in the era of digitalisation, a new, less recognisable, form of capture emerges. With the shift of communications online, and the increased use of key platforms to access information, the power to influence the information flow and manipulate our perception has intensified. Advanced monitoring, data collection, and analytics can be used by key media platforms to segment user groups and subtly control the information flows and news cycles (Ezrachi \& Stucke 2017). Advanced technology may also be used to manipulate general search online-from search results to manipulation of 'autocomplete' function in search (Epstein \& Robertson 2015).

In our new digitalised world, users and policymakers should not underestimate the true extent of platform power (Culpepper \& Thelen 2018). The growing awareness of this power has led to calls for closer monitoring of the online environment, to ensure a competitive and undistorted market for ideas.

In a recent speech, the EU Commissioner in charge of competition, Margrethe Vestager (2018), considered the social responsibility that emerges from the rising power of digital platforms, noting that:

the digital sector is one area where private businesses have become very influential in our societies, and where their level of responsibility towards society should rise to that of their influence. Social-media platforms have taken the world by storm. Billions of people love them. But we have also seen that these platforms can be abused. They can be abused to distort or fabricate information, manipulate people's views and degrade public debate.

\subsection{An illustration: (hostile) takeovers}

Developments in takeover policy provide a good illustration of how the forces of politics and special-interest pressures can erode the status quo via gradual or abrupt changes requiring little formal amendment to existing regulations. We focus on the UK, not only because it is a country that has ranked high for decades in international rankings measuring economic freedom, but more specifically because it has had exceptionally favourable rules for hostile takeovers for the last fifty years. 
Throughout the current decade, a crescendo of cross-party opposition to crossborder hostile takeovers, and then plainly to hostile takeovers, has yet to affect the fundamental pillars of UK takeover regulation. The decision on whether a takeover bid should succeed is still exclusively in the hands of the target shareholders and, whether through formal rules or institutional investors' pressure, listed companies are prevented from using durable founder control structures to avoid undesired attention from hostile acquirers.

To be sure, following pressures from both politicians and business leaders (Armour et al. 2011), the City Code has been tweaked in important ways after the CadburyKraft takeover, inter alia to ensure that any 'post-bid undertaking' is complied with. While such undertakings are purely voluntary, both in the run-up to the failed PfizerAstraZeneca takeover attempt and in the successful Softbank/ARM merger the government reportedly approached the bidders to make sure that they would bind themselves to post-offer undertakings, which they in fact did (Mor 2018). In addition, takeovers are already subject to enhanced government scrutiny: ${ }^{18}$ recently, the power to scrutinise mergers on 'public interest' grounds (Sections 58-59 of the Enterprise Act 2002) has been used to curb a British acquirer's discretion in disposing of the assets of a UK conglomerate with an aerospace division: the government authorised the acquisition of GKN by turnaround specialist Melrose only after the acquirer committed not to sell any of the core GKN Aerospace businesses for a period of five years and to maintain GKN's activities related to its role as a government defence supplier and contractor within the UK (Tovey \& Torrance 2018).

It is striking that, in line with the zeitgeist of a greater state involvement in economic affairs, the public debate on hostile takeovers in the UK predominantly focuses on giving the Government greater powers rather than on questioning the long-standing restrictions to tactical and structural corporate defences against takeovers (Kay Review 2012).

\section{CONCLUDING REMARKS}

Policymakers' primary challenge today is to cope with the effects of accelerated innovation and the disruption it generates across society. Our focus in the core of this paper (Sections 2-3) has been on the ways in which business law can be moulded to address such challenges. We have identified issues that deserve further attention from research as well as policymakers. We have also suggested improvements in the current

${ }^{18} \mathrm{~A}$ formal government proposal to give the government sweeping powers to protect 'national security from hostile actors' acquisition of control over entities or assets' was issued in July 2018 (BEIS, 2018). 
regulatory framework to facilitate the financing of innovation and to address the increased risks stemming from technology.

We then moved to a more procedural perspective and reflected upon the implications of the changing political climate-itself, to a large degree, the product of the digitalised environment we live in - for implementation of business law policies (Section 4). The rise of populism and the predicted intensification of large technology companies' effectiveness in shaping political outcomes do not warrant an optimistic assessment of society's ability to engineer business law as a means of optimising the challenges associated with innovation. For that very reason, though, it is essential to keep asking what a rational and evidence-based response to the current challenges should look like.

\section{REFERENCES}

Acharya, Viral V. \& Volpin, Paolo F. (2009), 'Corporate governance externalities', Review of Finance, 14(1): 1-33. https://doi.org/10.1093/rof/rfp002

Aghion, Philippe, Bond, Stephen, Klemm, Alexander \& Martinescu, Ioana (2004), 'Technology and Financial Structure: Are Innovative Firms Different?', Journal of the European Economic Association, 2: 277-88. https://doi.org/10.1162/154247604323067989

Aghion Philippe, Bloom Nick, Blundell Richard, Griffith Rachel \& Howitt Peter (2005), 'Competition and Innovation: An Inverted-U Relationship', Quarterly Journal of Economics, 120: 701-28.

Aghion, Philippe, Van Reenen, John \& Zingales, Luigi (2013), 'Innovation and Institutional Ownership', American Economic Review, 103: 277-304. https://doi.org/10.1257/aer.103.1.277

Andrus, Joseph \& Collier, Richard (2017), Transfer Pricing and the Arm's Length Principle after BEPS (Oxford, Oxford University Press).

Andrus, Joseph \& Oosterhuis, Paul (2017), 'Transfer Pricing After BEPS: Where Are We and Where Should We Be Going', Taxes-The Tax Magazine, March, 89-107.

Anton, Miguel, Ederer, Florian, Giné, Mireia \& Schmalz, Martin C. (2018), 'Innovation: The Bright Side of Common Ownership?, working paper, SSRN. https://papers.ssrn.com/sol3/papers. cfm?abstract_id=3099578

Arlen, Jennifer (1994), 'The Potentially Perverse Effects of Corporate Criminal Liability', Journal of Legal Studies, 23: 833-67. https://doi.org/10.1086/467947

Arlen, Jennifer \& Kahan, Arcel (2017), 'Corporate Governance Regulation through Nonprosecution', University of Chicago Law Review, 84: 323-87.

Armour, John (2018), 'AI and Corporate Governance', working paper, Oxford University.

Armour, John, Black, Bernard, Bernard, Cheffins, Bernard \& Nolan, Richard (2009), 'Private Enforcement of Corporate Law: An Empirical Comparison of the United Kingdom and the United States', Journal of Empirical Legal Studies, 6: 687-722.

https://doi.org/10.1111/j.1740-1461.2009.01157.x

Armour, John, Jacobs, Jack \& Milhaupt, Curtis (2011), 'The Evolution of Hostile Takeover Regimes in Developed and Emerging Markets: An Analytical Framework', Harvard Journal of International Law, 52: 219-85.

Armour, John, Mayer, Colin \& Polo, Andrea (2017), 'Regulatory Sanctions and Reputational Damage in Financial Markets', Journal of Financial and Quantitative Analysis, 52: 1429-48. https://doi.org/10.1017/S0022109017000461 
Armour, John, Gordon, Jeffrey \& Min, Geeyoung (2018a), 'Short-changing Compliance', working paper, Columbia Law School / Oxford University. http://dx.doi.org/10.2139/ssrn.3244167

Armour, John, Garrett, Brandon, Gordon, Jeffrey \& Min, Geeyoung (2018b), 'Board Compliance', working paper, Columbia Law School / Duke Law School / Oxford University.

Arrow, Kenneth J. (1962), 'Economic Welfare and the Allocation of Resources for Invention', in R. Nelson (ed.) The Rate and Direction of Inventive Activities: Economic and Social Factors (Princeton, NJ, Princeton University Press), 609-26. https://doi.org/10.1515/9781400879762-024

Auerbach, Alan \& Devereux, Michael (2018), 'Cash-flow Taxes in an International Setting', American Economic Journal: Economic Policy, 10(3): 1-27. https://doi.org/10.1257/pol.20170108

Auerbach, Alan, Devereux, Michael, Keen, Michael \& Vella. John (2017a), 'Destination-based Cash-flow Taxation', working paper 17/01, Oxford University Centre for Business Taxation.

Auerbach, Alan, Devereux, Michael, Keen, Michael \& Vella, John (2017b), 'International Tax Planning under a Destination Based Cash Flow Tax', National Tax Journal, 70: 783-802. https://doi.org/10.17310/ntj.2017.4.04

Avi-Yonah, Reuven, Clausing, Kim \& Durst, Michael (2009), 'Allocating Business Profits for Tax Purposes: A Proposal to Adopt a Formulary Profit Split', Florida Tax Review, 9: 497-543.

Azar, José, Schmalz, Martin C. \& Tecu, Isabel (2018), 'Anticompetitive Effects of Common Ownership', Journal of Finance, 73: 1513-65. https://doi.org/10.1111/jofi.12698

Azoulay, Pierre, Graff Zivin, Joshua S., Li, Danielle, \& Sampat, Bhaven N, (2017), 'Public R\&D Investments and Private-sector Patenting: Evidence from NIH Funding Rules, working paper 20889, National Bureau of Economic Research, Cambridge, MA.

Bamberger, Kenneth A. (2010), 'Technologies of Compliance: Risk and Regulation in a Digital Age', Texas Law Review, 88: 669-739.

Bebchuk, Lucian A. \& Kastiel, Kobi (2018), 'The Perils of Small-minority Controllers', working paper, Harvard Law School, Cambridge, MA.

Becker, Bettina (2015), 'Public R\&D Policies and Private R\&D Investment: A Survey of the Empirical Evidence', Journal of Economic Surveys, 29: 917-42. https://doi.org/10.1111/joes.12074

Bednar, Michael K. (2012), 'Watchdog or Lapdog? A Behavioral View of the Media as a Corporate Governance Mechanism', Academy of Management Journal, 55: 131-50. https://doi.org/10.5465/amj.2009.0862

BEIS (Department for Business, Energy \& Industrial Strategy) (2018), National Security and Investment (London, HMSO).

Berger, Allen N. \& Udell, Gregory F. (1998), 'The Economics of Small Business Finance: The Roles of Private Equity and Debt Markets in the Financial Growth Cycle', Journal of Banking and Finance, 22: 613-73. https://doi.org/10.1016/S0378-4266(98)00038-7

Bernstein, Shai (2015), 'Does Going Public Affect Innovation?', Journal of Finance, 70: 1365-403. https://doi.org/10.1111/jofi.12275

Birkinshaw, Julian (2018), 'How is Technological Change Affecting the Nature of the Corporation?', Journal of the British Academy, 6(s1): 185-214. https://doi.org/10.85871/jba/006s1.185

Brauner, Yariv \& Pistone, Pasquale (2017), 'Adapting Current International Taxation to New Business Models: Two Proposals for the European Union', Bulletin for International Taxation, 71.

Brownsword, Roger \& Goodwin, Morag (2012), Law and Technologies of the Twenty-first Century (Cambridge, Cambridge University Press). https://doi.org/10.1017/CBO9781139047609

Bushee, Brian (1998), 'The Influence of Institutional Investors on Myopic R\&D Investment Behavior', The Accounting Review, 73: 305-33. 
BVCA (2017), Private Equity and Venture Capital Report on Investment Activity 2016 (London, British Private Equity and Venture Capital Association).

Carpenter, Robert E. \& Petersen, Bruce C. (2002), 'Capital Market Imperfections, High-tech Investment, and New Equity Financing', Economic Journal, 112: F54-72.

https://doi.org/10.1111/1468-0297.00683

Clemons, Eric K., Reddi, Sashidhar P. \& Row, Michael C. (1993), 'The Impact of Information Technology on the Organization of Economic Activity: The 'Move to the Middle' Hypothesis', Journal of Management Information Systems, 10(2): 9-35. https://doi.org/10.1080/07421222.1993.11517998

Coase, Ronald H. (1937), 'The Nature of the Firm', Economica, 16: 386-405. https://doi.org/10.1111/j.1468-0335.1937.tb00002.x

Collin, Simon \& Karsenti, Thierry (2012), 'ICT and Migration: A Conceptual Framework of ICT Use by Migrants', working paper.

https://www.researchgate.net/publication/268447041_ICT_and_Migration_A_Conceptual_Framework _of_ICT_Use_by_Migrants

Culpepper, Pepper D. (2011), Quiet Politics and Business Power: Corporate Control in Europe and Japan (New York, Cambridge University Press).

Culpepper, Pepper D. \& Thelen, Kathleen (2018), 'It's Hard to Unplug from the Matrix: Consumers and the Politics of Platform Power', working paper, University of Oxford/Massachusetts Institute of Technology.

David, Paul A., Hall, Bronwyn H. \& Toole, Andrew A. (2000), 'Is public R\&D a Complement or Substitute for Private R\&D? A Review of the Econometric Evidence', Research Policy, 29: 497 529. https://doi.org/10.1016/S0048-7333(99)00087-6

De Loecker, Jan \& Eeckhout, Jan (2018), 'Global Market Power', working paper, National Bureau of Economic Research, Cambridge, MA.

Desai, Mihir A. \& Dharmapala, Dhammika (2018), 'Revisiting the Uneasy Case for Corporate Taxation in an Uneasy World', Journal of the British Academy, 6(s1): 247-84.

https://doi.org/10.85871/jba/006s 1.247

Devereux, Michael \& Vella, John (2014), 'Are We Heading Towards a Corporate Tax System Fit for the 21st Century?', Fiscal Studies, 35: 449-75. https://doi.org/10.1111/j.1475-5890.2014.12038.x

Devereux, Michael \& Vella, John (2017), 'Implications of Digitalisation for International Corporate Tax Reform', in Sanjeev Gupta, Michael Keen, Alpa Shah \& Genevieve Verdier (eds) Digital Revolutions in Public Finance (Washington, DC, International Monetary Fund), 91-112.

Devereux, Michael \& Vella, John (2018), 'Taxing the Digitalised Economy: Targeted or System-wide Reform?, British Tax Review, 301: 387-406.

Díez, Federico J., Leigh, Daniel \& Tambunlertchai, Suchanan (2018), 'Global Market Power and its Macroeconomic Implications', working paper, International Monetary Fund, Washington, DC.

Dyck, Alexander, Volchkova, Natalya \& Zingales, Luigi (2008), 'The Corporate Governance Role of the Media: Evidence from Russia', Journal of Finance, 63: 1093-135.

https://doi.org/10.1111/j.1540-6261.2008.01353.x

Easterbrook, Frank H. \& Fischel, Daniel R. (1991), The Economic Structure of Corporate Law (Cambridge, MA, Harvard University Press).

Elhauge, Einer (2015), 'Horizontal Shareholding', Harvard Law Review, 129: 1267-317.

Enriques, Luca \& Romano, Alessandro (2018), 'Institutional Investor Voting Behavior: A Network Theory Perspective', working paper, European Corporate Governance Institute. http://dx.doi.org/10.2139/ssrn.3157708

Epstein, Robert \& Robertson, Ronald E. (2015), 'The Search Engine Manipulation Effect (SEME) and its Possible Impact on the Outcomes of Elections', Proceedings of the National Academy of Sciences of the United States of America, 112(33): E4512-E4521.

https://doi.org/10.1073/pnas. 1419828112 
EU Commission (2018a), Proposal for a Council Directive Laying Down Rules Relating to the Corporate Taxation of a Significant Digital Presence, COM(2018) 147 final.

EU Commission (2018b), Proposal for a Council Directive on the Common System of a Digital Services Tax on Revenues Resulting from the Provision of Certain Digital Services, COM(2018) 148 final.

EU Commission (2018c), 'Taxation of Digital Activities in the Single Market', leaked internal document dated 26 February 2018, available at

https:/g8fip1kplyr33r3krz5b97d1-wpengine.netdna-ssl.com/wp-content/uploads/2018/02/taxationof-digital-economy-2.pdf.

Ezrachi, Ariel (2016), 'Sponge', Journal of Antitrust Enforcement, 5: 49-75. https://doi.org/10.1093/jaenfo/jnw011

Ezrachi, Ariel \& Stucke, Maurice (2017), Virtual Competition - The Promise and Perils of the Algorithm Driven Economy (Cambridge, MA, Harvard University Press).

Ezrachi, Ariel \& Stucke, Maurice (2018), Digitalisation and Its Impact on Innovation, European Commission research paper, DG Research and Innovation.

Fang, Vivian W., Tian, Xuan \& Tice, Sheri (2014), 'Does Stock Liquidity Enhance or Impede Firm Innovation?', Journal of Finance, 69: 2085-125. https://doi.org/10.1111/jofi.12187

Fell, Lisa-Marie \& Schreiber, Urlich (2017), 'International Profit Allocation, Intangibles and Sales-Based Transactional Profit Split', World Tax Journal, 9(1): 1-18.

Flammer, Caroline (2012), 'Corporate Social Responsibility and Stock Prices: The Environmental Awareness of Shareholders', working paper, MIT Sloan School of Management, Cambridge, MA.

FCA (2017), Guidance on the Duty of Responsibility: Final Amendments PS17/9, Financial Conduct Authority, London.

FRC (2016), The UK Corporate Governance Code-April 2016 Financial Reporting Council, London.

FRC (2018), The UK Corporate Governance Code-July 2018 Financial Reporting Council, London.

Freedman, Judith \& Vella, John (2016), 'Large Businesses: Tax Strategies and Sanctions for Persistently Uncooperative Behaviour', British Tax Review, 5: 653-63.

Geng, Heng, Hau, Harald \& Lai, Sandy (2016), 'Technological Progress and Ownership Structure', working paper, Centre for Economic Policy Research, London.

Gilson, Ronald J. (2003), 'Engineering a Venture Capital Market: Lessons from the American Experience', Stanford Law Review, 55: 1067-103.

Godfrey, Paul C., Merrill, Craig B. \& Hansen, Jared M. (2009), 'The Relationship Between Corporate Social Responsibility and Shareholder Value: An Empirical Test of the Risk Management Hypothesis', Strategic Management Journal, 30: 425-45. https://doi.org/10.1002/smj.750

Gompers, Paul A. \& Lerner, Josh (1999), The Venture Capital Cycle (Cambridge, MA, MIT Press).

Goshen, Zohar \& Hamdani, Assaf (2015), 'Corporate Control and Idiosyncratic Vision', Yale Law Journal, 125: 560-617.

Griffith, Sean J. (2016), 'Corporate Governance in an Era of Compliance', William and Mary Law Review, 57: 2075-140.

Guceri, Irem (2016), 'Tax Incentives for R\&D', working paper, University of Oxford.

Gutiérrez, Germán \& Philippon, Thomas (2018), 'How EU Markets Became More Competitive Than us Markets: A Study of Institutional Drift', working paper 24700, National Bureau of Economic Research, Cambridge, MA.

Hadfield-Menell, Dylan \& Hadfield, Gillian (2018), 'Incomplete Contracting and AI Alignment', working paper, University of California at Berkeley/University of Southern California.

Hall, Bronwen H. \& Lerner, Josh (2010), 'The Financing of R\&D and Innovation', in Bronwyn H. Hall \& Nathan Rosenberg (eds) Handbook of The Economics of Innovation, Volume 1 (Amsterdam, Elsevier), 609-39. https://doi.org/10.1016/S0169-7218(10)01014-2 
Hansmann, Henry \& Kraakman, Reinier (1991), 'Toward Unlimited Shareholder Liability for Corporate Torts', Yale Law Journal, 100: 1879-934. https://doi.org/10.2307/796812

Hansmann, Henry \& Kraakman, Reinier (2000), ‘The Essential Role of Organizational Law', Yale Law Journal, 110: 387-440. https://doi.org/10.2307/797521

Hart, Oliver \& Zingales, Luigi (2017), 'Companies Should Maximize Shareholder Welfare Not Market Value', Journal of Law, Finance and Accounting, 2: 247-75. https://doi.org/10.1561/108.00000022

He, Jie \& Tian, Xuan (2013), 'The Dark Side of Analyst Coverage: The Case of Innovation', Journal of Financial Economics, 109: 856-78. https://doi.org/10.1016/j.jfineco.2013.04.001

Haskel, Jonathan \& Westlake, Stian (2018), Capitalism without Capital. The Rise of the Intangible Economy (Princeton, NJ, Princeton University Press). https://doi.org/10.1515/9781400888320

Heath, Joseph, Moriarty, Jeffrey \& Norman, Wayne (2010), 'Business Ethics and (or as) Political Philosophy', Business Ethics Quarterly, 20: 427-52. https://doi.org/10.5840/beq201020329

HM Treasury (2018), Corporate Tax and the Digital Economy-Position Paper Update.

Horwitz, Morton J. (1979), The Transformation of American Law, 1780-1860 (Cambridge, MA, Harvard University Press).

Kaplan, Steven N. (2013), 'CEO Pay and Corporate Governance in the US: Perceptions, Facts, and Challenges', Journal of Applied Corporate Finance, 25(2): 8-25.

https://doi.org/10.1111/jacf.12013

Kaplan, Steven N. \& Strömberg, Per (2003), 'Financial Contracting Theory Meets the Real World: An Empirical Analysis of Venture Capital Contracts', Review of Financial Studies, 70: 281-315.

Karpoff, J. M., Lott, J. R. Jr. \& Wehrly, E. W. (2005), 'The Reputational Penalties for Environmental Violations: Empirical Evidence', Journal of Law and Economics, 48: 653-75. https://doi.org/10.1086/430806

Karpoff, J. M., Lee, \& Martin, G. S. (2008), 'The Cost to Firms of Cooking the Books', Journal of Financial and Quantitative Analysis, 43: 581-611. https://doi.org/10.1017/S0022109000004221

Kay Review (2012), 'Kay Review of UK Equity Markets and Long-term Decision Making: Final Report'. https://www.gov.uk/government/consultations/the-kay-review-of-uk-equity-markets-and-long-termdecision-making

Kostovetsky, Leonard \& Manconi, Alberto (2018), 'Common Institutional Ownership and Diffusion of Innovation', working paper, SSRN. https://papers.ssrn.com/sol3/papers.cfm?abstract_id=2896372

Krumm, Brian K. (2018), 'Fostering Innovation and Entrepreneurship: Shark Tank Shouldn't Be the Model', Arkansas Law Review, 70: 553-608.

Marino, Marianna, Lhuillery, Stephane, Parrotta, Pierpaolo \& Sala, David (2016), 'Additionality or Crowding-out? An Overall Evaluation of Public R\&D Subsidy on Private R\&D Expenditure', Research Policy, 45: 1715-30. https://doi.org/10.1016/j.respol.2016.04.009

Mayer, Colin (2013), Firm Commitment (Oxford, Oxford University Press).

Mayer-Schönberger, Viktor \& Ramge, Thomas (2018), Reinventing Capitalism in the Age of Big Data (London, John Murray).

McBarnet, Doreen (2007), 'Corporate Social Responsibility beyond Law, through Law, for Law: The New Corporate Accountability', in Doreen McBarnet, Aurora Voiculescu \& Tom Campbell (eds) The New Corporate Accountability: Corporate Social Responsibility and the Law (Cambridge: Cambridge University Press), 9-58.

Milanovic, Branko (2016), Global Inequality: A New Approach for the Age of Globalization (Cambridge, MA, Harvard University Press). https://doi.org/10.4159/9780674969797

Miller, Geoffrey P. (2018), 'An Economic Analysis of Effective Compliance Programs', in Jennifer Arlen (ed.) Research Handbook on Corporate Crime and Financial Misdealing (Cheltenham, Edward Elgar), 247-62. https://doi.org/10.4337/9781783474479.00019 
Mor, Federico (2018) Contested Mergers and Takeovers', House of Commons Library, Briefing Paper 5374.

Murphy, Deborah L., Shrieves, Ronald E. \& Tibbs, Samuel L. (2009), 'Understanding the Penalties Associated with Corporate Misconduct: An Empirical Examination of Earnings and Risk', Journal of Financial and Quantitative Analysis, 44: 55-83. https://doi.org/10.1017/S0022109009090036

Nanda, Ramana \& Rhodes-Kropf, Matthew (2016), 'Financing Risk and Innovation', Management Science, 63: 901-18. https://doi.org/10.1287/mnsc.2015.2350

OECD (2017a), OECD Digital Economy Outlook 2017 (Paris, OECD Publishing).

OECD (2017b), Entrepreneurship at a Glance 2017 (Paris, OECD Publishing).

OECD (2018), Tax Challenges Arising from Digitalisation-Interim Report 2018 (Paris, OECD Publishing).

Pargendler, Mariana (2018), 'The Grip of Nationalism on Corporate Law', working paper, SSRN. SSRN: https://ssrn.com/abstract=3144451

Parliamentary Commission on Banking Standards (2013), Changing banking for good: Report of the Parliamentary Commission on Banking Standards, HL Paper 27-I and 27-II; HC 175-I and 175-II (London, HMSO).

Pew Research Center (2017), Automation in Everyday Life (Washington, DC, Pew Research Center).

Piketty, Thomas (2014), Capital in the Twenty-first Century (Cambridge, MA, Harvard University Press). https://doi.org/10.4159/9780674369542

Posner, Eric A., Scott Morton, Fiona M. \& Weyl, E. Glen (2017), 'A Proposal to Limit the Anticompetitive Power of Institutional Investors', working paper, SSRN. https://papers.ssrn.com/sol3/papers.cfm?abstract_id=2872754.

Prassl, Jeremias (2018), Humans as a Service: The Promise and Perils of Work in the Gig Economy (Oxford, Oxford University Press). https://doi.org/10.1093/oso/9780198797012.001.0001

PwC (2018) Getting Ahead of the Watchdogs: Real-time Compliance Management: 2018 State of Compliance Study PricewaterhouseCoopers.

Royal Society (2018), How Does UK Investment in R\&D Compare Internationally?. https://royalsociety.org/ /media/policy/projects/investing-in-uk-r-and-d/how-does-UK-investment -in-R-and-d-compare-internationally-large.jpg.

Sabel, Charles, Herrigel, Gary \& Kristensen, Peer Hull (2017), 'Regulation Under Uncertainty: The Coevolution of Industry and Regulation', Regulation and Governance, 12: 371-94. https://doi.org/10.1111/rego.12146

Schumpeter Joseph (1942), Capitalism, Socialism and Democracy (New York, Harper and Brothers).

Shapira, Roy (2018), 'Law as Source', working paper, IDC Law School.

Shavell, Steven (1980), 'Strict Liability Versus Negligence, Journal of Legal Studies, 9: 1-25. https://doi.org/10.1086/467626

Stein, Jeremy C. (1988), 'Takeover Threats and Managerial Myopia', Journal of Political Economy, 69: 61-80. https://doi.org/10.1086/261524

Tovey, Alan \& Torrance, Jack (2018), 'Government Nods Through Melrose’s £8bn Takeover of GKN', The Daily Telegraph, 24 April.

https://www.telegraph.co.uk/business/2018/04/24/gkn-splurged-100m-deal-fees-run-up-melrosetakeover/.

Vestager, Margrethe (2018), 'A Responsibility to Be Fair'.

https://ec.europa.eu/commission/commissioners/2014-2019/vestager/announcements/responsibilitybe-fair_en

Williamson, Oliver E. (1985), The Economic Institutions of Capitalism: Firms, Markets, Relational Contracting (New York, Macmillan). 


\section{APPENDIX: RECOMMENDATIONS FOR FURTHER RESEARCH}

\section{Financing innovation-focused businesses}

\section{Positive externalities}

The UK's level of government investment in R\&D trails many other developed countries, and so does its corresponding level of private R\&D. Based on the emerging picture from the more recent research, it would be desirable to explore how public investment can be delivered most effectively to stimulate growth in private R\&D.

\section{Venture capital}

What explains the very low level of venture capital investment in the UK, relative to private equity as a whole? Is this because of lack of opportunities for investment? Or is it because of a 'crowding-out' effect of easy access to public firm targets for buyouts, facilitated by a prohibition on defensive tactics for public company boards?

\section{Common ownership}

Further work into aggregate effects and - especially-case studies of the channels through which any influence is exercised, would be most valuable.

\section{Durable founder control}

Does restricting such structures entail a constraint on financing innovative $R \& D$ investments? Are there ways in which agency costs in such structures could be mitigated?

\section{$R \& D$ tax incentives}

Further work into the effects on relocation, patenting, and increases in productivity would be valuable.

\section{Market structure}

What should be the state's approach to consolidation in the digital sector? How can one optimise the incentives of firms to invest in welfare-enhancing innovation?

\section{Competition law}

What is the adequate level of intervention in digital markets? Is the current analytical framework fit to address the challenges from digitalisation? 


\section{Digitisation in business and organisations}

Smart contracts and firms $v$ markets

How are smart contracts being used in ways that substitute for the corporate form? To what extent is this motivated by reductions in transaction costs, or by regulatory arbitrage? What are the policy implications?

\section{Emergent social risks and corporate reputation}

Can we determine the value to firms of their 'political' reputation? In order to achieve a clean identification of the political reputation channel, it is desirable to identify a case where firms make reports regarding their performance vis-à-vis third parties, which does not itself entail any legal risk.

\section{Technology and monitoring}

What problems exist regarding 'goal alignment' with internal performance monitoring systems for corporations?

\section{Corporate governance and compliance}

1. What is, or will be, the effect on managerial incentives, including vis-à-vis compliance, of extending the vesting period for stock-based pay from three to five years for UK public companies, and from five to seven years for UK banks?

2. What is or will be the impact on financial firm managers of the new duty of responsibility introduced by the FCA's senior managers regime? What implications can be drawn from this for stimulating compliance incentives in non-financial firms?

3. What has been the impact of Hong Kong's mandating of corporate reporting about compliance efforts?

\section{Ownership}

Does concentrated ownership imply a better alignment between corporations' and societal interests when it comes to emergent social risks? Are there any cultural, market, tax, and legal obstacles to durable founder (and, more generally, controller) control structures that stand in the way of allowing a real choice between the various kinds of ownership structures?

\section{Forward compliance}

What are the prospects for establishing a functioning system of 'forward compliance' in UK public companies? 


\section{International corporate tax law}

There is a need to carefully study the proposals made in response to digitalisation which seek to reform the existing system while maintaining its existing fundamental structure. These proposals, including digital permanent establishments, turnover taxes, and withholding taxes, raise a number of concerns. Alternative systems should continue to be studied, in particular systems that only partially move to a destination basis. These systems harness some of the benefit of a move towards destination while appeasing the political concerns which would arise from a more comprehensive move towards destination. Further research is required on reform proposals targetting 'digital' companies (including digital Permanent Establishments and Digital Services Taxes) as well as proposals that seek to reform the system as a whole (including proposals which move - in whole or in part — towards a destination basis of taxation).

\section{Business law reforms and the political climate}

Business law making in the digital era

How have the dynamics of the production of business law changed in Western democracies following digitalisation?

\section{Property rights in firms in the time of post-liberalism}

To what degree has the balance between corporate and state control of business organisations changed following the switch in public opinion's views on the respective roles of markets and governments?

\section{International corporation tax}

How does the current political climate impact international tax cooperation?

\section{The political economy of concentrated ownership}

Can we expect a trend towards more concentrated ownership also as an outcome of the change in the relative powers of the state vis-à-vis markets?

\section{Competition enforcement}

To what extent are the diverging views as to the benefits of antitrust intervention the result of intellectual and regulatory capture, lack of sufficient independence of competition authorities, or pressure from policymakers?

\section{Nationalisation}

If formal or informal nationalisation is looming as one possible outcome of the current political climate, what lessons can we learn from past moves in the same directions? 
Global supply chains and the return of protectionism

What would be the industrial organisation and corporate governance effects of a newly compartmentalised trade environment?

\section{Note on the authors}

John Armour is Professor of Law and Finance at Oxford University and a Fellow of the British Academy and the ECGI. He has held visiting posts at the University of Chicago, Columbia Law School, the University of Frankfurt, the Max Planck Institute in Hamburg, and the University of Pennsylvania. Armour has published widely in the fields of corporate law and financial regulation. His books include Principles of Financial Regulation (OUP, 2016) and The Anatomy of Corporate Law (3rd edn, OUP, 2017). He is an Executive Editor of the Journal of Corporate Law Studies and the Journal of Law, Finance and Accounting. He has been involved in policy-related projects commissioned by the UK's Department of Trade and Industry (now BEIS), Financial Services Authority (now FCA) and Insolvency Service, the Commonwealth Secretariat, and the World Bank. From 2014 to 2017 he served as a member of the European Commission's Informal Company Law Expert Group which advised on issues including digitisation of company law and cross-border corporate transactions.

Luca Enriques is the Allen \& Overy Professor of Corporate Law at Oxford University and a Fellow of the ECGI. He has held visiting posts at Cambridge University, Columbia Law School, Cornell Law School, Harvard Law School, and IDC Herzliya. His fields are corporate governance and financial regulation with a focus on comparative and European law. He is an Editor of the Journal of Corporate Law Studies, the European Business Organization Law Review, and the Capital Markets Law Journal. Current research projects focus on the use of network theory to improve our understanding and the regulation of financial markets, the impact of technology on corporate governance, and EU securities regulation.

Ariel Ezrachi is the Slaughter and May Professor of Competition Law and a Fellow of Pembroke College, Oxford. He serves as the Director of the University of Oxford Centre for Competition Law and Policy. He is co-editor-in-chief of the Journal of Antitrust Enforcement and the author, co-author, editor and co-editor of numerous books, including Virtual Competition - The Promise and Perils of the Algorithm Driven Economy (Harvard, 2016), EU Competition Law-An Analytical Guide to the Leading Cases (6th edn, Hart, 2018), and Intellectual Property and Competition Law: New Frontiers (OUP, 2011). His recently published papers focus on the digital economy, e-commerce, parity clauses, marketplace bans, vertical agreements, buyer power, and the limits of competition law. 
John Vella is Associate Professor of Taxation at Oxford University and a Fellow of the Oxford University Centre for Business Taxation. He has held visiting posts at New York University, Georgetown University, and the University of Sydney, and was a visiting scholar at the International Monetary Fund. Vella's recent research has focussed on the taxation of multinationals, financial sector taxation, and tax compliance and administration. He has given evidence on these issues on a number of occasions both before UK Parliamentary Committees and Committees of the European Parliament.

To cite the article: John Armour, Luca Enriques, Ariel Ezrachi and John Vella (2018), 'Putting technology to good use for society: the role of corporate, competition and tax law', Journal of the British Academy, 6(s1): 285-321.

DOI https://doi.org/10.5871/jba/006s1.285

This article is licensed under a

Creative Commons Attribution-NonCommercial-NoDerivs 4.0 Unported License.

Journal of the British Academy (ISSN 2052-7217) is published by

The British Academy - the national academy for the humanities and social sciences.

10-11 Carlton House Terrace, London, SW1Y 5AH

www.britac.ac.uk 
